\title{
The Column Para noče de šabat as a Local Strategy of Memory of the Judeo-Spanish Tradition
}

\begin{abstract}
The article elaborates on the attempts of the editors of the Jewish weekly Jevrejski glas (published in Sarajevo in 1928-1941) to support fostering of the Sephardi tradition and Judeo-Spanish language during the period in which an inevitable process of language shift took place among the Sephardi citizens of Bosnia. The column Para noče de šabat, created with the help of the weekly's readers, was one of the means serving that purpose. In the majority of the texts the main characters were Sephardi women, especially of the older generation, the women called tijas (aunts). For that reason, the paper presents how the authors showed female characters in the context of memory of "the true Sephardi spirit and tradition." Additionally, we provide basic information on the gathered texts: linguistics and sociolinguistics of the language of the prose (its condition, lexis and local features), as well as the characteristics of narration.
\end{abstract}

Keywords: Sarajevo, the Jewish press, Judeo-Spanish, Ladino, short stories, sketches, amateurish prose, memory.

\section{Jevrejski glas and the Jewish Press in Bosnia}

Since the second half of the nineteenth century the modern Sephardic press printed in Judeo-Spanish in the Ottoman Empire had several crucial functions: apart from its informative role, its goal was to create a new kind of Jewish readers, of all ages and social status, and to offer them educational content promoting progress within Jewish communities as well as to integrate them. The press also aroused the interest of Sephardic 
readership in new literary genres such as novels and short stories. ${ }^{1}$ In the Sephardic centers, for instance Istanbul and Salonica, it was the longlived periodicals El Tyempo and La Epoka that had led the field since the 1870s. They were also read in great many Sephardic communities in the Balkans. In the territory of later Yugoslavia first attempts to publish the modern local Sephardic press were made in Serbia at the end of the nineteenth century. This signalled the beginning of El amigo del puevlo (Belgrade) and El luzero (Zemun) which, however, did not last as long as their equivalents in Istanbul and Salonica. The Bosnian Sephardi community gained its first and only Judeo-Spanish periodical on the cusp of 1900 and 1901 when Abraham Cappon self-published La Alborada, which introduced the Bosnian Sephardi readers to their first samples of Judeo-Spanish prose, drama, and poetry. After some time, however, Cappon failed in his efforts for lack of funds. In Bosnia successful Jewish periodicals were printed in the Kingdom of Yugoslavia after World War I. They were run in a professional way, supported financially and published in different political, social, and cultural conditions of westernization and acculturation of the Bosnian Jews.

When the first issue of one of these periodicals, Jevrejski glas [The Jewish Voice], was published in 1928, it meant a symbolic end to a socalled "Sarajevian conflict (or dispute)." A collision of Zionism and the Sephardic Movement is one of the most interesting phases of the pre-war Jewish history of Bosnia. We can observe the beginnings of the Sephardic Movement at the end of the nineteenth century, when this national ideology appeared together with the start of westernization of Sephardim. It assumed special significance in the 1920s under the influence of the Vienna and Zagreb association Esperansa. The Bosnian propagators of the movement were not against Zionism, but above all put effort into the emancipation of the Sephardim, to go along with the preservation of the Sephardic identity and tradition.

Jevrejski glas was supposed to be a tribune which would combine the profiles of both fractions-Zionist and pro-Sephardic. The role of the new magazine was strongly underlined in the first issue, in the manifest on the first page:

${ }^{1}$ Sarah Abrevaya Stein, Making Jews Modern: The Yiddish and Ladino Press in the Russian and Ottoman Empires (Bloomington, 2004); Olga Borovaya, Modern Ladino Culture: Press, Belles Lettres, and Theatre in the Late Ottoman Empire (Bloomington, 2012), 23-74.

${ }^{2}$ Cvi Loker, "Sarajevski spor i sefardski pokret u Jugoslaviji," Zbornik Jevrejskog istorijskog muzeja 7 (1997), 72-78. 
"Jevrejski glas" nastojaće da svakom pravcu i svakoj struji u Jevrejstvu, koji idu za unapređivanjem naše jevrejske zajednice, iziđe u susret iskrenim shvatanjem za njihove težnje i najvećim gostoprimstvom primi u svoje stupe njihova izlaganja. Vodeći računa o tome, da je, uslovljeno stoljetnom istorijom i neizbrisivim tradicijama, naša zajednica po svome sastavu prilično složena, ići će novo glasilo za time da sve te raznolike elemente stavi u jedan aktivan odnos prema zajednici kao takvoj i da njihova nastojanja podredi jednom višem principu, a to je jedinstvo jevrejskoga naroda i zajednička sudbina sviju Jevreja. ${ }^{3}$

[Jevrejski glas will continue to meet any direction and movement in Jewry that keeps our Jewish community abreast of time with sincere appreciation of its pursuits and welcome them on our pages with the greatest hospitality. Bearing in mind that our community conditioned by centuries-old history and living traditions has a very complex constitution, the new body will advocate to combine all those different elements into a united active attitude toward community as it is, and to submit all its pursuits to a single, paramount rule which is the unity of Jewish nation and common fate of all Jews]. ${ }^{4}$

Jevrejski glas presented the situation of the Jewish world on the local, Balkan, and international level. The magazine was mostly printed in SerboCroatian $^{5}$ and the linguistic policy of the magazine shows the sociolinguistic situation in the Bosnian Sephardic community: the years 1918-1941 are the period during which Bosnia was part of the Kingdom of Yugoslavia and all Jews were its rightful citizens. It was a period of acculturation for most Sephardic Jews, opening up their participation in public life and, in linguistic terms, a period of bilingualism during which the Serbo-Croatian language was being acquired and an inevitable process of language shift took place among the Sephardi citizens of Bosnia.

\section{The Column Para noče de šabat as a Strategy of Memory}

Nevertheless, despite being a press institution of the united local SephardiAshkenazi community, the magazine, according to the guidelines of its editorial board, did not neglect efforts to foster the Sephardi tradition and the Judeo-Spanish language. For that reason, in 1931 the editors of the weekly (printed mostly in Serbo-Croatian) started the column titled

3 Jevrejski glas (1928), 1:1.

${ }^{4}$ All texts are translated by the authors of the paper. In the case of Judeo-Spanish fragments of the short stories quoted in the paper, philological translation is used.

${ }^{5}$ We use the term "Serbo-Croatian" as we mention the Slavic language in Bosnia between two world wars, long before the official recognition of the Bosnian language in 1995. 
Para noče de šabat [For the Shabbat Night] and called on the readers to create its content:

De oj adelantre, en kada numero de nuestra gazeta vamos trajer akontesimientos, anekdotas, dialogos, proverbios etc. de nuestra vida. Kon esto no keremos azer solo pasatiempo a muestros lektores i daldes okazion para reir, sino konservar en eskrita el esperitu de muestras maales, muestra lingua, muestros ekspresiones i modo de pensar, en kurto dičo muestro folklor. En esteso tiempo jamamos a todos muestros lektores de ajudarmos en esto ečo. I akel ke no save eskrivir nos puede ajudar dandomos en 2-3 palavras material para esta rubrika; solo la fabula, la konseža sin estilizarla i komponarla nos puede servir para esta rubrika porke la redaksion sola la va, antes de estamparla, korižir i redigar. ${ }^{6}$

[Starting from today, in every issue of our weekly we will present events, anecdotes, dialogues, proverbs, etc., from our life. In this way we want to bring not only entertainment for our readers and make them laugh, but we also want to preserve in script the spirit of our maales (neighborhoods), our language, our expressions and way of thinking, in brief-our folklore. At the same time, we call upon our readers to help us out with this goal. Those who can't write can help us by providing content in 2 or 3 words; even a story, la konseža,${ }^{7}$ without stylizing or arranging can serve a purpose in this column, since the editorial team is going to correct and redact it before printing].

As a result of the call, until 1937 many pieces of Judeo-Spanish prose, mostly amateurish in character, appeared in the column together with proverbs and kantikas. $^{8}$ As Muhamed Nezirović wrote, ${ }^{9}$ the cooperation of the magazine with local authors and readers willing to create the content of the column Para noče de šabat was a huge success-the texts were indeed widely read. Our collection of prose texts from the column includes 47 samples of longer stories, short anecdotes, and sketches. ${ }^{10}$ Some of them were signed with their authors' names and surnames (Miko Altarac, Moni Finci), but most used pseudonyms, nicknames, or initials (M.M.P., p., Jakoviku, Josefiko, Uno di la Bilava, Cadik, Lević, Jehi, Jafi, Mi and, in one case, Bohoreta - Laura Papo). All the texts of the section which we used for this research are listed below ${ }^{11}$ :

${ }^{6}$ Jevrejskiglas (1931), 5:7. Let us observe that in this text, despite its brevity and importance (it was an opening text of the column), there appear different spelling variants of the same word (nuestra/muestra).

7 (Jud.-Sp.) 'a short story,' genre of the Judeo-Spanish oral tradition.

8 (Jud.-Sp.) 'a song,' the Judeo-Spanish oral tradition's genre of lyrical character.

${ }_{9}$ Muhamed Nezirović, Jevrejsko-španjolska književnost u Bosni (Sarajevo, 1995), 566.

${ }^{10}$ Out of them three brief anecdotes were published in the same issue of the newspaper: Jevrejski glas (1932), 3:5.

11 We mainly had access to the issues of Jevrejski glas (JG) archived in the Jewish community of Bosnia and Herzegovina in Sarajevo. Several issues are probably missing. 
1. Anonymous texts: "Las katorze. Istoria verdadera" [Fourteen O'clock. A True Story] (JG 1928, 4), "No ti ulvidis, doktor..." [Don't Forget, a Doctor...] (JG 1932, 1), "Para ti komo amigo" [For You As a Friend] (JG 1932, 3), "Na i Mirjam" [And Mirjam] (JG 1932, 3), "Si, si...” [Yes, Yes...] (JG 1932, 3), "Tija Bijara no komi paža” [Tija Bijara Is Not Easy to Bribe] (JG 1932, 22), "Shakitu ainda no si sano" [Shakitu Still Is Not Recovering] (JG 1934, 5);

2. Bohoreta (Laura Papo): "Ajde a mirar peši!...” [Let's Go to Look at Fish!] (JG 1936, 18);

3. Cadik (an unknown author): "Tija Lunača” [Tija Lunača] (JG 1931, $50)$;

4. Jehi (an unknown author): "Kun il amargu" [Over a Cup of Coffee] (JG 1934, 7);

5. Jafi (an unknown author): "La oja di tija Strulača” [Tija Strulača's Pot] (JG 1936, 3), "Il pustu 'Jezero"” [The Damn "Lake"] (JG 1936, 4);

6. Jakoviku (an unknown author): "Tija Oru i la amiga al gjardin" [Tija Oru and Her Friend in the Garden] (JG 1936, 9), "Tiju Mušon onde el ižo" [Tiju Mušon Visiting His Son] (JG 1936, 20);

7. Josefiko/Josefikos (an unknown author): "Tardi di vjarnis” [Friday Afternoon] (JG 1931, 45), "Ni li ičo lebaio" [He Didn’t Greet Him] (JG 1931, 52), "No li tukava ičar talet" [It Was Not Her Turn to Cover with Tallit] (JG 1932, 4), "Fazjendu il anjo di Liđa" [Taking a Bath in Ilidža] (JG 1932, 10), "Tiju Mušon i las hadras di Pesah" [Tiju Mušon and Arrangements for Pesach] (JG 1932,17-18), “Turnandu di la Kisela...” [Returning from Kiseljak] (JG 1932, 42), "Tija Strulača jeva mal kun il jarnu” [Tija Strulača Doesn't Get along with Her Son-in-Law] (JG 1932, 52), "Tija Bulka no si hue esti anju a la Kisela!" [Tija Bulka Didn't Go to Kiseljak This Year!] (JG 1933, 40);

8. Lević (an unknown author): "Lu di Saraj non aj in sieti partis de el mundo" [There Is No One Like People from Sarajevo in Seven Parts of the World] (JG 1931, 51);

9. MI/Mi (an unknown author): "Tres čupadas de mjel en el skuro" [Three Sips of Honey in the Dark] (JG 1932, 9), "Tija Simhula" [Tija Simhula] (JG 1932, 12);

10. Miko Altarac: "Las enbonoras de tija Bonača" [Good-byes of tija Bonača] (JG 1931, 46), "Loke loz vježos kerijan intri shvenjo liz vinija" [What Old People Wanted in Their Dreams Came True] (JG 1931, 48), "Loke todo es oj odern" [Why Is Everything Modern Nowadays] (JG 
1932, 2), "Loke es el, dr. o ez pr." [Who Is He, Dr. or Prof.?] (JG 1932, 6), "'En tu kaza santa iremos, in en luvia, i en njevi, i en todo tjempo" ["To Your Holy Home We Will Go, in the Rain, in the Snow, in any Weather"] (JG 1932, 20);

11. M.M.P. (an unknown author): "Pur no ir tonta al otru mundu" [Not to Leave for the Otherworld Being Stupid] (JG 1932, 7), "Las di agora" [These (People) of Today] (JG 1932, 8), "Lu kerin atučar" [They Want to Marry Him to Someone] (JG 1932, 11), "Ki bjen ki mi lavi" [Let Him Wash Me Well] (JG 1932, 13), Para noće de šabat [For the Shabbat Night] (JG 1932, 19), "Ken es ombri, ken mužer?" [Who Is a Man, Who Is a Woman?] (JG 1937, 6), "Tija Strulača en el mar" [Tija Strulača at the Seaside] (JG 1938, 45), "Tija Strulača en la Makarska” [Tija Strulača in Makarska] (JG 1937, 50), "Sretna Nova Godina" [Happy New Year] (JG 1937, 3);

12. Moafi (Moise Finci): "Tonfilm" [Sound Film] (JG 1933, 18);

13. Moni Finci: "Lus livjanus di tija Hanuča" [The Treatments of tija Hanuča] (JG 1933, 51), "Un kamino a Banjaluka" [The Road to Banjaluka] (JG 1934, 10, 18);

14. p. (an unknown author): "Loke mos akapita en muestros dias..." [What Happens to Us in Our Times] (JG 1928, 3), "Aftaha ke no venran todos... (Una istoria vera)" [The Hope That Not Everybody Will Come... (A True Story)] (JG 1928, 5), "Kon ke estima se andan oj platos... (Una de las konvencionalidades)" [Nowadays Dishes Are Prepared With Such Respect (One of Conventionalities)] (JG 1928, 7);

15. Uno de la Bilava / Unu di la Bilava (an unknown author): "El primer paputo para luvia en el munturo" [The First Raincoat in the Bad Weather] (JG 1931, 42), "La štasjon de Jerušalajim" [The Station Jerusalem] (JG 1931, 47).

This list does not cover all the texts in the Para noče de šabat. In comparison to the inventory compiled by Nezirović, it lacks, for example, some texts by Moni Finci, Jakoviku, Josefiko, Uno de la Bilava, and M.M.P., but on the other hand Nezirović does not mention the anonymous items contained in our list.

It should be mentioned that the call for texts for the upcoming column did not appear before 1931. Nevertheless, we found three texts signed by an author who used the nickname p., which were published in the issues $1,2,{ }^{12} 3,5$, and 7 of Jevrejski glas in 1928 at the very beginning of article.

${ }^{12}$ We did not have the texts of the first two issues in our collection while writing this 
the existence of the magazine. Apart from their titles, they also had the same heading, Para noče de šabat. There was also one anonymous text, "Las katorze. Istoria verdadera." This might suggest that the editors had the idea of creating such a space in the newspaper long before it was officially brought into existence. We also agree with Nezirovic that it is possible that Benjamin Pinto, the then chief editor, used the pen name $\mathrm{p} .{ }^{13}$ He used to sign other texts with Pinto, Pinto Benjamin, Bepo, or be. p.

Even though the stories, anecdotes, and other texts published in the column were to be taken from the readers' everyday lives, the editors' intention was not only to portray them as a part of the contemporary reality or to provide entertainment, but also "to preserve in script" Sephardic practices and customs which, at that time, could be still observed amongst Sephardim, and yet were subject to change at the time of modernization. This latter aspect turned out to be most valuable in light of the later fate of the Balkan Jews, when they experienced migrations which led to the dissolution of the Sephardic community in the Balkan states, the Holocaust, and the near extinction of Judeo-Spanish.

In the early 1930 s the founders of the column were already aware that they were facing a gradual decline in the traditional Sephardic world; this was why they wanted to gather short narratives that included elements of the traditional lifestyle. One element, common to all the texts, was the vernacular language of the Sephardim that in this period still was naturally associated with the sphere of tradition, folklore, and familiarity. Changing attitudes toward it in the community and some kind of gap between the old and the young generation with respect to the language issue found its expression in several stories. The authors mainly portrayed the problem with humor and a sense of detachment, but did not seem to take sides in this confrontation, probably because the texts included in this section did not have a distinctly critical purpose. The reason was that the genres of anecdotes and short narratives were not the most appropriate for developing deep criticism. Focusing on a problem in an amusing and light-hearted way, however, made readers more inclined to ponder over it.

The editors' aims were also exposed in a commentary preceding three short sketches in issue 3 in 1932:

Antes de enpesar a la rubrika, dišimos, ke no keremos solo kon eja azer reir a la đente, sino mustrar la muestra vida i su alma, el modo de pensar de las

${ }_{13}$ Nezirović, Jevrejsko-španjolska književnost, 604. 
ženerasjones ke se estan deperdiendo, sus logika etc. Oj trajemos 2-3 estampas de esta vida, ondi se veje la primitividad de muestras maales en una manera muj avierta i klara. ${ }^{14}$

[Before we started this column, we said that not only did we want to make people laugh, but also to show our life and its soul, the way of thinking of the generations which are disappearing, their mindset, etc. Today we bring 2 or 3 scenes illustrating this life in which the primitiveness of our quarters can be seen in an open and clear manner].

This fragment—especially the word "primitiveness" employed in this context—reveals consciousness of the rift between old times and modern thinking as well as a general approval of modernity. Nevertheless, it does not show any struggle against tradition and an old-fashioned lifestyle.

The idea of creating Para noče de šabat may be considered a strategy of memory because what had existed mainly in oral transmission and was prone to be abandoned and forgotten due to the intensive transformation of the Sephardic community could be later recorded in print and circulated among readers. This process portrays the strategy of memory which consists in writing. Magdalena Koch, ${ }^{15}$ in a study devoted to survival strategies of Sephardic women in Bosnia, identifies the act of writing with the re-construction of history. The author analyzes the case of Laura Papo Bohoreta who wrote her essay La mužer sefardi de Bosna [The Sephardic Woman in Bosnia] in the years 1931-1932, more or less at the time when Para noče de šabat was founded. She described the everyday lives of Sephardic women according to oral accounts of two older generations of her relatives and acquaintances. Her work was in the form of a manuscript and was published only after she died. It was not until more than seventy years had passed that it appeared in print. Interestingly, this first edition contained two versions: the facsimile of handwritten Judeo-Spanish texts by Papo and its Bosnian printed translation by Muhamed Nezirović. ${ }^{16}$ Koch draws attention to the fact that the act of writing down the past by Papo would have been insufficient as a survival strategy had it not been completed much later by Nezirović. Thus, she considers translating and printing Papo's work another survival strategy.

In the case of Para noče de šabat both survival strategies occurred at almost the same time or at least it should be assumed that the period

${ }^{14}$ Jevrejskiglas (1932), 3:5.

15 Magdalena Koch, "Lost-Regained-Revised: Laura Papo Bohoreta, Sephardic Women in Bosnia, and Transcultural Survival Strategies in Memory," this issue, 7-30.

${ }^{16}$ Laura Papo Bohoreta, Sefardska žena u Bosni (Sarajevo, 2005). 
between the moment of putting down the story and publishing it was short. Nevertheless, the editors may also have played the role of intermediaries between the real authors' work and the readers. In the call for texts they announced they would make all the necessary adjustments or even write the whole stories based on brief sketches sent by the audience. That is why in the column not only do we find stories signed by some well-known authors (e.g. Bohoreta, Benjamin Pinto), but also anonymous ones or ones signed with nicknames which were difficult to identify. In fact, we have no information about whether there were really any stories written by the editors on the basis of someone's oral narration. If so, we do not know whether a name or a nickname appearing below such a text belongs to a reader or an editor.

Assuming that writing stories for Para noče de šabat was a strategy of memory, the question arises as to whether we deal with the memory of one particular gender or perhaps a gendered memory. As far as we know, only one text was explicitly signed by a woman (Bohoreta). Generally, considering the post-Ottoman region, few female authors were mentioned as having written texts in Judeo-Spanish before the 1940s ${ }^{17}$ Nevertheless, as the column was to be co-authored by the readers, we must highlight the fact that women were allowed to answer this call for stories too. As Joanna Lisek claims in the case of Yiddish authors, women's texts had easier access to sections devoted to readers' works than to other main columns of the newspaper which were strongly dominated by men. ${ }^{18}$ Possibly this was also true for Para noče de šabat. Had it not been the case, we should not speak about women's strategy of memory or much less about women's gendered memory. Nevertheless, one can observe that in the collection of characters females predominate and, apart from a few exceptions, are sketched in a more vibrant fashion than men. The most numerous are tijas-elderly women and wives who have almost adult children. Moreover, there appear wives with small children, marriageable young girls, modern young girls, daughters, neighbors, and so on. Apart from Sephardic women, Ashkenazi

${ }^{17}$ See: Paloma Díaz-Mas, Elisa Martín Ortega, "Lecturas para mujeres y mujeres escritoras en la cultura sefardí," in eaed. (eds.), Mujeres sefardíes lectoras y escritoras, siglos XIXXXI (Madrid-Frankfurt am Main, 2016), 31-33; Elisa Martín Ortega, "Las primeras escritoras sefardíes, entre tradición y modernidad: Dos textos de Reina Hakohén de Salónica," MEAH. Sección Hebreo 62 (2013), 145-175, http://www.meahhebreo.com/index.php/meahhebreo/article/view/116/272 [retrieved: 20 Jan. 2018]. See also about an author who used a female nickname: Elena Romero, "Mlle. Elisa: Una periodista sefardí," in Díaz-Mas, Martín Ortega (eds.), Mujeres sefardies lectoras y escritoras, 197-206.

18 Joanna Lisek, Kol isze - głos kobiet w poezji jidysz (od XVI w. do 1939 r.) (Sejny, 2018). 
or Serbo-Croatian women are also occasionally portrayed. Sometimes the main characters are men. Other times there are texts in which only men appear. More often than not, they are described by women who talk about their husbands, sons, sons-in-law, or other people's relatives. These depictions are filtered through female narration. Interestingly, a double filter was used. We must remember that the image of women preserved in the majority of texts included in the column was filtered according to male perception. This is because we assume that the texts were written mostly by men. Reconstructing women's history and their cultural gender roles in the Bosnian Jewry of the first three decades of the twentieth century, we are left to take this image into account, since we have scarce number of texts revealing the proper voice of Sephardic women.

It is evident that in the strategy of memory carried out in Para noče de šabat the image of women turns out to be one of the central elements of the traditional way of life which the authors wanted to retain in their stories. This could be explained by the fact that females helped to maintain and pass to the next generations long-established values, traditional mentality, and lifestyles with practices and customs. In the early 1930s they were also widely associated with the Judeo-Spanish-speaking community, more often than men were. ${ }^{19}$

\section{The General Linguistic Characteristics of the Texts}

The texts included in the section vary in length, language, and subject. Some are short (shorter than one-third of a column on a multi-column page),${ }^{20}$ but most take up two or even three columns. There is also a story divided into chapters: "Un kamino a Banjaluka" by Moni Finci.

Para noče de šabat was written with Latin script that replaced the Rashi script in the Jewish press in Bosnia after the end of World War I. In the 1920s the editorial board of the weekly Jevrejski život [The Jewish Life] defined its own rules of Judeo-Spanish orthography based

${ }_{19}$ About processes of modernization of Sephardic communities in the Eastern Mediterranean region in the nineteenth and twentieth centuries see: Paloma Díaz-Mas, María Sánchez Pérez, "Los sefardíes ante los retos del mundo contemporáneo," in eaed. (eds.), Los sefardíes ante los retos del mundo contemporáneo: Identidad y mentalidades (Madrid, 2010), 11-29.

${ }^{20}$ E.g. "Loke nos akapita en muestros dias...," "Aftaha ke no venran todos...," both signed with "p.", or "Las katorze," an anonymous text. 
on Serbo-Croatian Latin script ${ }^{21}$ and a few years later Jevrejski glas retained it for its own purposes. Nevertheless, the editors of the newspaper did not fully standardize spelling, which differs not only for various authors but also for different texts by the same author or even within one text. Due to the lack of consistent standardization we find various spellings of the same phonemes, such as: gjente/djenti/dente [people], djudija/džudija (a Jewish woman), mučos/mućos [many]. To give an example, in "Tija Simhula" by the author signed with "Mi" there appear such variants as fambre/fambri, vinder/vender, and burikona/burekona. In several stories the spelling usually corresponds to a Bosnian variant in Judeo-Spanish, provided we consider only the tendency to pronounce (and thus write) the non-stressed vowels -e as -i, -o as -u, and in some contexts -e as -a, as in the following example: "I ven mi fižitju, ven ondi tu madri kada vjernis la midjudija, ti fazire un pastilikju afružaldadu, miraras umpoku il mulinu ... In estu ja intro la nuera. Mi bizo lo manu i ki pardunemus un puntu ki luegu va turnar"22 [Come, my little boy, come to your mother every Friday at noon, I will make fruit biscuits for you, you will look at the grinder for a while ... At that moment the daughter-in-law entered. She kissed my hand and apologized as she was going to come back a little bit later].

In many fragments we might observe vacillation and lack of standardization in relation to this aspect. There are also stories which almost entirely diverge from this rule, e.g. "Aftaha ke no venran todos..." by the author signed with "p."

Regarding the lexical corpora of the texts, we should mention borrowings and influences of various origins. Of course, the Hebrew-Aramaic component mainly refers to the area of religion, cult, religious customsthat is, non-physical areas: micva (a good deed), aftaha (hope), hamec (leavened bread), tanit (fast), kal (a synagogue), darsar (to preach), malah (an angel), mazal (happiness), zahut (a good deed, charity), hen (grace), baal afiaha (an optimist), binadam (a man), bizdradel (with God's help),

21 "Tomando en konsid[e]rasion las kondisiones ke governan onde mozotros, tokante la lingua i el modo de eskrivir mos dečizimos al modo fonetiko, ke es skrivir komo se melda i kon letras latinas. Savemos auna, ke esto no es muestra manera de skrivir, otro ke deviamos ke publikar los lavoros espanjoles en la letra raši, ma komo dičo, las pezgadias tehnikas no mos alisensian esto." [Taking into consideration the conditions in respect of the language and manner of writing, we decided on the phonetic manner, which follows the pronunciation of Latin letters. Although we know that this is not our manner of writing and that we should publish Spanish articles in the Rashi script, as we have already stated, technical obstacles did not allow us to do so]; "Muestras publikasjones en espanjol," Jevrejski život (1924), 28:2.

22 “Tija Bijara no komi paža,” Jevrejski glas (1932), 22:5. 
etc. By contrast, the lexis of Turkish origin is most often related to material culture, artefacts, trades, though it also denotes various aspects of social life: minder (a piece of furniture), čakširis (a pair of trousers), tapet (a carpet), parlak (cut diamond), kujundži (a goldsmith), muštuluk (a piece of news), čarši (a bazaar), avli (yard), kira (rent), musafir (a guest), englena (fun), bulukis (crowds), haitir (bow; respect).

The presented corpora do not seem to differ much from the JudeoSpanish lexis in other Sephardic centers in the Balkans such as Salonika and Monastir (Bitola). ${ }^{23}$ The most interesting aspects and what makes the gathered texts distinct are local linguistic and lexical features, such as German and Slavic influences on the language. The influences from German are rare, e.g. entšuldign (excuse me), hercig (lovely), apiteki (the chemist's), banof (a railway station). Undoubtedly, some were taken directly from the Serbo-Croatian language, which has been demonstrated in such forms as šnajderica (a female tailor).

Most of the Slavic (Serbo-Croatian) elements in the texts illustrate the sociolinguistic situation of the Sephardic minority in Sarajevo; the period of the language shift process involving the stage of bilingualism. ${ }^{24}$ Therefore, in the resources we can find many Serbo-Croatian words which permeated the Judeo-Spanish texts, among them also the forms resulting from the Judeo-Spanish and Serbo-Croatian interference: tramvajis (trams), zilinikja (pita with spinach), škola (a school), gazdarica (a housekeeper), guspodin (a mister), zaljubijar (to fall in love), blaha/blahu (a non-Jew), "mi faleja la društva" [I missed some company], "stamos aki na zeleno" [here we are, in the bosom of nature], "la šolja in manu" [the cup in hand], "il kave un poku sjempri mas plavitju" [each time coffee is lighter], "antes sin i esta ljubav ja moz kazavamos" [earlier we used to get married without this love], "me dizi la Bukica ki si zaljubio" [Bukica told me that she had fallen in love], "omladina del čarši i omladina del Poale Cijon" [youth of the bazaar and youth of Poale Zion], "i lu glavno" [and what is the most important], and "Dišu ki kali operacija, ki tjeni slepo crevo" [He said that he needed an operation, that he had a blind gut].

${ }^{23}$ See, for instance, the classic research on Judeo-Spanish in the Balkans such as: Cynthia M. Crews, Recherches sur le judéo-espagnol dans les pays balkaniques (Paris, 1935); Max A. Luria, A Study of the Monastir Dialect of Judeo-Spanish Based on Oral Material Collected in Monastir, Yugo-Slavia (New York-Paris, 1930).

${ }^{24}$ For more details about the studies on the sociolinguistic situation of the Bosnian Sephardim between two world wars, see Ivana Vučina Simović, Jevrejsko-španski jezik na Balkanu (Kargujevac, 2016). 
In some cases the characters illustrated in the column Para noče de šabat use whole Serbo-Croatian phrases, sayings, or proverbs: "E, e nisam ja bolesna, ovaj je Shakitu" [I am not sick, it is Shakitu who is], "fala Bogu" [thank God], "jašta molim ti" [come on, of course!], "ni pet ni šes" [something incongruous], "Bože moj” [My God], "Neće grom u koprivo" [highly improbable that something will happen].

Occasionally, as in stories "No ti ulvidis, doctor" or "Lu de Saraj non aj en sjeti partis de el mundo" the Sephardi characters who are in contact with non-Jewish surroundings or with educated and assimilated Jews speak two languages: Judeo-Spanish and Serbo-Croatian, for example: "Ej, kočijaš. Ajdi da me nosiš do Dušanova ulica 14, i molim te da mi ne voziš brzo ... Tražim moja kćerka. Kako ne znaš, malmazal, ona iz Sarajeva"25 [Hey, driver. Take me to Dušanova Street 14, and, please, don't go fast ... I'm looking for my daughter. How come you don't know, goddamn, she is from Sarajevo]. What we might find significant is that the SerboCroatian language of the Sephardim in the texts is poor and grammatically incorrect. This additionally illustrates a sociolinguistic situation found in the bilingual Sephardic community in Sarajevo. ${ }^{26}$

\section{The Literary Characteristics of the Texts}

Generally, the language in the section is colloquial and imitates the way the lower and middle class spoke. Sometimes we observe an endeavor to distinguish the characters on the basis of language, and thus the idiolects of elderly women differ from the ones of the young. As explained above, young people who represent the ideals of modernization and have a tendency toward integration use much more words or whole sentences in Serbo-Croatian. In some cases, the contrast between two different

25 "Lu de Saraj non aj en sjeti partis de el mundo," Jevrejski glas (1931), 51:7.

${ }^{26}$ In the same period Jewish writers who chose Serbo-Croatian as the language of their literary works, e.g. Isak Samokovlija, would introduce Judeo-Spanish words and expressions into them. For both speech communities this was an allusion to the reality which they knew and which did exist nearby. However, the environment where Ladino was already spoken started to be perceived as old-fashioned, and thus Ladino was replaced by SerboCroatian. It could also be observed that in the second half of the twentieth century and in the twenty-first century, when the Sephardim ceased to speak Judeo-Spanish worldwide, authors of memoirs and novels connected with the Sephardic past also introduced expressions of this language into their works written in other languages (English, French, Spanish, Serbo-Croatian, Turkish, etc.). Nonetheless, in our times the function of this literary device seems to be different than before World War II-it provokes nostalgia or brings the reader closer to the remote and bygone realities of the first diaspora countries. 
styles of speech turns out to reveal a crucial concept of the structure of the story. Either a third-person narrative or, very rarely, a first-person narrative is used, the latter being an interesting instrument for building closeness between the narrator and the audience (see "Tija Lunača" by Cadik or "No ti ulvidis, doctor"). This is often complemented by dialogues which make the stories more authentic and vivid. There are stories with no central narrator as well-then an anecdote is presented only from the point of view of the characters in a dialogue. Dialogue is the principal means of expressing ideas and of distinguishing characters. Another way of cutting the distance between the story-teller and the reader is to use the second-person plural (e.g. "Loke mos akapita en muestros dias...," "Kon ke estima se mandan oj platos..." by p., and "La štasjon de Jerušalajim" by Unu di la Bilava) as in the following examples: "Perdonadmi, seniores leedores, kon la mas mižor intension vos ago atento ke en dia de šabat no se visten tefilim ningun modo" 27 [Forgive me, dear readers, I would like to draw your attention to the fact that one should not wear tefillin on the Shabbat] or "Vos topaš en una fiesta i veš al deredor de vozotros, en la meza, en el armario, en una kamareta, en la otra kamareta, un mučedumbre de platos, prezentes: čikos, grandes, sin grande valor, de grande presio, ma todos lindos i ermozos" ${ }^{28}$ [You are at a party and around you, on a table, in a sideboard, in one room and in another one, you see many plates with dishes: small, big, of no great value and of high price, but all of them are cute and beautiful]; "A tija ... todos la konoseš; kada vjarnis vendi ruda i paulijas para el kandil de šabat i antes de Hanuka mečas para las hanukijas, i este feču aj ke tieni anjus i panjus"29 [Tija ... you all know her; every Friday she sells rue and wicks for Shabbat candles and before Hanukkah tapers for hanukkiahs. She has been doing this job for many, many years].

In the first quoted fragment the narrator seems to be an expert who clarifies the details necessary to understand the anecdote, and in the second and the third ones he appeals to the readers' experience and imagination to make the described situations more authentic and familiar. The third excerpt has an interesting device which consists in showing a character who is to impersonate a typical representative of some group: a nameless

\footnotetext{
27 “Lo ke nos akapita en nuestros dias," Jevrejski glas (1928), 3:5.

28 p.,"Kon ke estima se mandan oj platos...," Jevrejski glas (1928), 7:4.

29 Unu di la Bilava,"La štasjon de Jerušalajim,” Jevrejski glas (1931), 47:7.
} 
tija who sells rue and wicks every Friday seems to be the person whom every reader can meet in his or her own town or neighborhood. ${ }^{30}$

From a literary perspective, the texts are unsophisticated and quite simple. However, they are characterized by some diversity. This is mainly manifested in the number of characters, the role of the narrator, and the place of dialogues. For instance, there are stories which begin with a description of circumstances - the weather, a season of the year, a festive day, or a place. Others open directly with a dialogue or in medias res. A few texts employ a kind of a frame: they begin and close with a similar scene-for example, a woman visits her neighbor, she greets her and they have a chat, and at the end this situation is mirrored in the scene of farewell, with the guest neighbor usually having to leave because she has much housework to do (e.g. "Lus livjanus di tija Hanuča" by Moni Finci, "Loke todo es oj moderno" by Miko Altarac). The motif of a visit paid to a neighbor is repeated in several stories and is a handy way of both portraying everyday routines of Sephardic women, usually representative of traditional part of society, and of showing their mentality, attitudes to different subjects, as well as topics which most matter to them.

\section{The Image of Sephardi Women in the Texts of the Column}

As mentioned, each of the short stories and sketches of the column had a limited number of characters and mainly focused on females who were very expressive and had particular attitudes. Based on the types of the main female characters in the column, the texts can be easily divided into three main groups. There are stories that present:

(1) elderly Sephardi women in their traditional surroundings leading their traditional lives. This group of texts introduces the everyday life of so-called tijas, a Judeo-Spanish word with a quite broad meaning. According to the dictionary of Joseph Nehama it is " 1 . an aunt, a sister of mother or father; 2 . an elderly woman, a relative or an acquaintance; 3. a title given to a woman of older age, of humble origins." ${ }^{11}$ In the texts

${ }^{30}$ Even if we take into consideration a different artistic level, the effect is similar to the one created in a famous and masterly phrase by Cervantes: "In a village of La Mancha, the name of which I have no desire to call to mind." Miguel de Cervantes Saavedra, Don Quixote, trans. John Ormsby, http://www.gutenberg.org/cache/epub/996/pg996.html [retrieved: 1 Feb. 2018].

31 Joseph Nehama, Dictionnaire du judéo-espagnol (Madrid 1977), 551. 
tijas are elderly women of humble origins, having their own families or single, rather well known in the community;

(2) Sephardi tijas in clash with social progress, the attitudes and customs of younger generations, especially Jewish young women, Sephardic as well as Ashkenazic;

(3) young emancipated Jewish women, bringing the cultural and social progress within the local Sephardic community. It has to be mentioned that there are very few texts in the column in which young Jewish women are presented as the main characters. Usually they are just family members or are portrayed in opposition to the image and attitudes of the generation of tijas. The marginalization of young generations in the column Para noče de šabat is striking, as Sarajevo in the 1930s was definitely a period of emancipation and acculturation for Jewish women, which is also illustrated in other prose samples published in Jevrejski život or Jevrejski glas outside the column presented here, e.g. in the texts by Laura Papo, Avram Romano Buki, and Benjamin Pinto. ${ }^{32}$

Everyday life of Sephardi women (especially tijas) is the main motif of the texts in the column. It is almost always presented as simple, traditional life, confined to a few main circles: the hometown Saraj (Sarajevo), the local Sephardi community, mahale (a neighborhood), kurtižo $o^{33}$ (a yard), and family. In that pattern one can easily find the cultural heritage of the patriarchal Sephardi life in the Ottoman Empire, when the female sphere and activity were in fact limited to the closest familiar surroundings, unlike the male, public sphere.

A typical tija does not work outside the home, but accepts being confined in the space customarily regarded as feminine. She spends time exercising her domestic responsibilities that in some periods are more numerous, especially before holidays on the liturgical calendar or life-cycle celebrations. Despite the burden which results from living in accordance with all gender roles imposed on women by a traditional society, she does not seem

${ }^{32}$ See: Vučina Simović, Jevrejsko-španski jezik, 214-216; Jelena Filipović, Ivana Vučina Simović, "La lengua como recurso social: El caso de las mujeres sefardíes de los Balcanes," in Díaz-Mas, Sánchez Pérez (eds.), Los sefardíes ante los retos del mundo contemporáneo, 259-269.

${ }^{33}$ On kurtižo as a women's space see: Agnieszka August-Zarębska, "The Representations of kurtijo and Their Function in Contemporary Judeo-Spanish Poetry," in Andrzej Kątny, Izabela Olszewska, Aleksandra Twardowska (eds.), Ashkenazim and Sephardim: A European Perspective (Frankfurt am Main, 2013), 245-268; Agnieszka August-Zarębska, Zuzanna Bułat Silva, "Recalling the Past: The Linguistic and Cultural Images of Kurtijo, Sephardic Courtyard," Anthropological Journal of European Cultures 25 (2016), 1:96-117. 
to support the idea of inverting this order. On the contrary, she is shown as a true guardian of tradition. So as to manage to do her work better, she seeks little strategies to avoid additional tasks or resorts to other women's solidarity within the established frames of performing mutual favors.

A character exemplifying this is Rinuča in a story without a title by M.M.P., describing preparations for Pesach (las hadras). She tries to carry out all the duties and fulfil the demands connected with the festivity, although their number seems to be beyond her strength. The author highlights that what makes the work more difficult is its combination with childcare:

Enus sež dijas manka para Pesah i Rinuča no savi ondi va dar la kavesa inprimeru. No skapa un feču, vjeni il otru sin pinsar i, kvandu kirijamus kuntar todu luke fazi di la madrugada fin aja medja noći, no pudijamus in su suluk. In esta ribultina sta di dija in dija, finki no si vjeni al šefoh, kvandu no so la alma, sino i il kuerpu kunsjenti ki vinu muet. Todu estu li era a Rinuča preza di burmuti, si no tinija la tartagana di krijaturas las kvalas no kerin saver si si aserka Pesah o Tišabeav, kerin kumer komu kada dija. ${ }^{34}$

[It is about six days before Pesach and Rinuča doesn't know what she should get down to doing first. She doesn't even end one task when another one appears and if we were to list everything she did from dawn to dusk, we wouldn't be able to do it in the same breath. This bustle continues day by day until Shefok $h^{35}$ comes, when not only the soul but also the body feels that moed has arrived. All this would be for Rinuča like a pinch of snuff, if she did not have a few children, who don't even want to know that Pesach or Tesh'a be-av is approaching and they want to eat as every day].

These days every extra chore causes her annoyance and to avoid a conflict with her husband she invents strategies to get rid of the children. She also asks favors of other women (such as taking care of her son for a few hours-the famous tenemaka $)^{36}$ which will be returned at another time. ${ }^{37}$

34 “Para noče de šabat," Jevrejski glas (1932), 19:6.

${ }_{35}$ Shefokh hamatkha means a prayer recited at the Seder.

${ }^{36}$ The habit of sending children to the neighbors' or family's house so that they can be looked after outside home while their mother is occupied with her duties. "Di aji vuz važ avagar, avagar onde nona manseva, li kontas komu sto skafisida di la kavesa, tengu mučus fečus. La saludas, aruganduli ki ti de komu god savi un poku di tenemaka" [From there walk slowly to your grandma, tell her that I am very busy and have many chores to do. Greet her and ask her to give you a bit of tenemaka (literally "keep me here")]; ibid.

${ }^{37}$ A very appreciated kind of aid was curing illnesses and indispositions using folk healer's methods, as in "Shakitu ainda no si sano": "ja bati ala puerta tija Hanuča kon una čanta de tinđires, kučarones, ruda, menta, in kurtu: kun la apoteki suja entera" [Tija Hanuča already knocked on the door, with her bag full of utilities, ladles, rue, mint, in short: with her entire pharmacy]; "Shakitu ainda no si sano," Jevrejski glas (1934), 5:5. 
The simple life of Sephardic women has its own rules and rhythm, marked with repetitive accents of the day, week, or year, including resting after housework on a Friday afternoon or the visiting with neighbors for a cup of coffee, which obviously played a significant role in the lives of mahale, as we can read in the dialogues of tijas: "No puedi ser la vižita sin kave" 38 [There cannot be a visit without coffee]; "Tija Rifkule, ajdi ja abasto fazer fečus, luke es, Pesah no va ser, ajdi abaši, biviremus un pretu"39 [Tija Rifkule, come on, let's stop working or Pesach won't come, come around, let's have a cup of black coffee]; “esti guezmu di kave fresku, mi sta ariturnando la alma. . . . Ja keru i jo biver un kave, ja mi si inšugo la boka" ${ }^{40}$ [this scent of coffee restores my spirit. ... - Yes, I want to have a cup of coffee, too, it makes my mouth water].

Those accents and rhythms of everyday problems and visits integrated the women from the neighborhood; as a result, they could rely on each other. They created strong, familiar relations with each other, as in the case of tija Rifkula and her neighbors:

Buenus dijas i salud i vidas! Mi sejas bjenvinida . . . Ja savis komu ez. Vizina keda sjempri vizina. Las krijaturas si van a la škola, lus mansevus si van al lavoru, ansina ki kedu jo sola in kaza. La varda ki ti diga, la maz grandi dizgrasja ez ki non aj kun ken spartir una palavra. Il maz grandi gustu mi ez, kvandu mi vjeni a vižitar alguna vizina. ${ }^{41}$

[Have a good day and health, and life! Welcome ... You know how it is. A neighbor is always a neighbor. Children go to school, the youth go to work so I stay home alone. To tell the truth, the biggest worry is that there is nobody to talk to. And it is such a delight for me when a neighbor comes for a visit].

As Jelena Filipović and Ivana Vučina Simović write, Sephardi women: "Las mujeres, aunque culturalmente marginadas, desarrollaban sus propios métodos de influencia, encontrando unas vías para ejercer un poder social sin entrar en el terreno del poder público (reservado para los hombres)" ${ }^{\prime 2}$ [Women, although culturally marginalized, developed their own methods of influence, finding ways to exercise a social power without entering the area of public power (reserved for men)]. Therefore, as both authors observe, in their private, familiar limited sphere Sephardi women created the supportive communities of practices (Sp. comunidades

\footnotetext{
38 “Tija Strulača jeva mal kun il jarnu,” Jevrejski glas (1932), 52:5.

39 Josefiko, "Tardi di vjarnis," Jevrejski glas (1931), 45:7.

40 M.M.P., "Las di agora," Jevrejski glas (1932), 8:7.

${ }^{41}$ Jafi, "Il pustu 'Jezero'," Jevrejski glas (1936), 4:3.

${ }^{42}$ Filipović, Vučina Simović, "La lengua como recurso social," 264.
} 
de práctica) - a group in which every member is responsible for another and every member works at the well-being of the group, ${ }^{43}$ as is illustrated in the texts of the column. The characters share problems, information, and news; they gossip, and support each other by asking and giving advice as well as by offering and receiving help. The texts in the column illustrate that the female sphere is extended to the women's section in a synagogue. All the generations meet there: young girls, newlyweds, mothers, and old ladies, all displaying a wide range of typical behaviors. It is a place where they chat, meet people, observe relatives, neighbors, and acquaintances, shown in a critical as well as humorous way. They admire their friends' new hats and even exchange recipes for nut cake and meatballs. ${ }^{44}$

In the community of the Sephardi women the opinions of neighbors are crucial and firm. Every member of the community has a particular role or function or is well known and recognized for her skill (e.g. being an acclaimed cook or an expert at folk medicine), an attribute or a quality (e.g. tija Lunača and her dementia). Those firm roles and functions also regulate social life, relations, hierarchy, and respect within the inner community: "Non aj balabaja la ke no konose a tija Strulača 'la ojandija.' Tambien no aj balabaja la ke no sentjo de maravijas por las ojas di tija Strulača.... Kali saver ke non es tan kulaj de ganar ansina un estimado "nombre de mued"" 45 [There is no housekeeper who does not know tija Strulača, "the pot lady." Neither is there a housekeeper who has not heard about tija Strulača's dishes... . You should know that it is a "prestigious nickname," it is not easy to get]; "ja si savi ke Strulača ez una de las maz onoradas mužeris i ke azi mučo bondades i entritodo es vera đudja"46 [it's well known that Strulača is one of the most respected women, she does many good deeds and, above all, she is a true Jew].

In several texts a character or a narrator claims that another character is a good or a true Jew. In old Sephardic mahales people were not anonymous; they knew each other quite well and had their own opinions about their neighbors. For example, in "Las enbonoras de tija Bonača" by Miko Altarac, an elderly widow is regarded by the narrator as a good Jew: "Eja es de las dudajkas grandis" ${ }^{47}$ [She is one of these good Jews]. She has no family in

${ }^{43}$ Ibid.

${ }^{44}$ See: Miko Altarac, "En tu kaza santa iremos, in en luvia, i en njevi, i en todo tjempo," Jevrejski glas (1932), 20:7.

45 Jafi, "La oja di tija Strulača," Jevrejski glas (1936), 3:3.

${ }^{46}$ Ibid.

${ }^{47}$ Miko Altarac, “Las enbonoras de tija Bonača,” Jevrejski glas (1931), 46:6. 
the town; thus, charitable neighbors support her in different ways. Every week tija Bonača has a Shabbat meal with another family, a young boy walks to the synagogue with her and aids her in crossing the street, a neighbor's daughter is asked by her mother to darn Bonača's clothes or to go with her to the railway station to buy a ticket for her. The elderly woman has never bought one by herself and is unfamiliar with prices. As she does not have enough money, a part of the fare is paid without her knowledge. The author suggests that this solidarity of members of the community, which guarantees safety, comes from the fact that they are good people and good Jews. He remarks: "La kaza de Strulača de Buhor era la mas đudajka, por esto tija Bonača lu maz kerija venir a sintir kiduš o ovdala onde Buhor" 48 [The home of Strulača, the Buhor's wife, was the most Jewish and that's why tija Bonača wanted to go there to listen to kiddush and Havdalah most often]. For the Sarajevian tijas presented in the column Para noče de šabat it is the allegiance to well-known surroundings which ensures the status quo in traditional cultural and social life. In many texts of the column, when a tija crosses the line of a safe, well-recognized territory, the simple Sephardi life is endangered or the characters face new phenomena that they do not understand, which provokes feelings of alienation. For some characters, it is the neighborhood of Bjelave (before World War II inhabited mostly by poor Sephardi families) situated in the hills, which is a safe territory. Getting married and raising families within the community of Bjelave enabled fostering of the Jewish tradition, while people from the town center and in mixed marriages could seriously shake the fundaments of the Sephardi heritage. That is why tija Bijara was unhappy when her son moved down to the town center to live with his wife, an Ashkenazi Jewish girl:

avjendu en la bilava tantas mučačas, kuriladas, komu la kungja, tu abašatis a la sivdad a tumar šuaba. ... no aj pastel, no aj čuftikjas, no aj šabat la minjana guevu kun raki, sino es kumer kave di leči komu kada dija ${ }^{49}$

[having so many girls in Bjelave, ruddy as roses, and you came down to the town to get a German. . . . there is no pastry, there are no $\check{c}$ uftikjas, ${ }^{50}$ there is no egg with raki on Shabbat morning, but they have white coffee every day].

${ }^{48}$ Ibid.

49 “Tija Bijara no komi paža."

${ }^{50}$ A Sephardic Passover dish consisting of fried, carved leek stems (looking like whistles), see: Elli Kohen, Dahlia Kohen-Gordon, Ladino-English / English-Ladino Concise Encyclopedic Dictionary (New York, 2000), 93. 
If other neighborhoods could be confusing and abstruse for an elderly Sephardi woman, so were foreign cities, as in a story telling how a tija visits her daughter in Belgrade and feels like a total stranger outside her well-known community:

No vejis vezindado, no tjenis kun ken spantir dos palabras. Jo sto anbizada asentar kun vizindado, bever kave, avlar. . . . Aji las karas diskunisidas . . Belogrado no es para los viježos. Belogrado es para la manseverija kvalos no bilkejan nada nada ${ }^{51}$ [You do not meet anybody from the neighborhood, there is nobody to talk to. I am used to sitting with neighbors, having coffee and talking. ... There are only strange faces ... Belgrade is not for old people. Belgrade is for the young who do not care about anything, anything].

There is thus no doubt that the characters of the traditional women in the stories feel comfortable in their natural, old-fashioned surroundings and experience unease when they encounter a different mode of living. Several texts develop the topic of confrontation of values traditionally appreciated in the community compared to a new, progressive lifestyle. Tijas are puzzled when they see people who choose modernization, have difficulty in understanding their choice and usually are highly critical of them. It is significant that the main target of their judgements are women, especially young ones. Sharing these critical opinions with other neighbors gives them strength and comfort.

Ideas on these matters are exchanged, for example, in "Las di agora": two women are unified by the smell and taste of coffee-a kind of leitmotif in the whole story stressing their common beliefs. First, Strulača blames a young woman for marrying a gentile (blahu) and the woman's mother for allowing it. She says: "No si naskan maz ansina fižitas, mižor li era ala madri si si li inšuvagan las tripas i no huera paridu" 52 [Such girls should not be born, it would have been better had her mother's womb withered and she hadn't given birth]. Her neighbor Beja is cautious about replying, as she still has a marriageable daughter. Other aspects of modern life criticized by both friends include such topics as a small number of children in modern marriages, the lateness of the first delivery, thinness of pregnant women, and the supposed general laziness of wives. Some, despite having few children, do not do household chores by themselves but employ servants. They do not even need to prepare hot dinner for their husbands when they return from the office. The symbol of contemporary

51 "Lu de Saraj non aj en sjeti partis de el mundo."

${ }^{52}$ M.M.P., "Las di agora." 
comfort is never having to soak one's hands in cold water. The visit ends because the neighbors need to return to their duties. Beja's husband wants to have his soup hot when he gets home, and if he is not satisfied with what he sees at home, he will reproach his wife for spending time with neighbors. The construction of the story is interesting since the life and way of speaking of the characters is juxtaposed to a different lifestyle, which they criticize. Their traditionalism is also emphasized by the fact that they use proverbs and herbs and amulets (e.g. garlic and rue) to protect themselves from disease. The same ideas are developed in "Loke todo es oj moderno" by Miko Altarac. Here the characters talk about the problem of not observing the rules of kashrut. ${ }^{53}$

As shown, marrying a person from outside the Sephardic and broadly Jewish community is one of the main troublesome situations which may happen to a family. This motif is repeated in several texts. Another aspect criticized by tijas is a new pattern of relationships in which love is the most significant factor and partners may have a long-term relationship before marriage. The character in "Tija Oru i la amiga al gjardin" tells the story of a beautiful young girl who dates a student who was studying to become a lawyer. Her parents were convinced their daughter would marry him, but he left her. Oru says: "ajajaj esta pusta 'sloboda' ke dešan a las mučačas solas kun lus mansevos" 54 [oh my, this "freedom" of letting girls be alone with boys].

We can observe general support for arranged marriages. In "Kun il amargu" a neighbor remarks:

Vejis vizina, vejis komu es oj kun las fižas? Ulvidati, ulvidati, ja paso akel tjempu kunado kazavan a las fižas komu lus đinitores kirijan. Oj, kuandu aj kinos i eškolas es huarti, muy huarti es kun ejas ${ }^{55}$

[Do you see, my neighbor, do you see how it is with daughters nowadays? Forget it, forget it - the times when daughters got married like parents wanted them to have already passed. Nowadays, when there are cinemas and schools, daughters are difficult, so difficult].

This fragment expresses disapproval not only about trends in choosing a partner, but also about the modern education system in which girls are included, as well as the fact that contemporary entertainment is open for both sexes.

\footnotetext{
${ }^{53}$ Miko Altarac, "Loke todo es oj moderno," Jevrejski glas (1932), 2:6.

${ }^{54}$ Jakoviku, “Tija Oru i la amiga al gjardin,” Jevrejski glas (1936), 9:7.

55 Jehi, "Kun il amargu," Jevrejski glas (1934), 7:7.
} 
In "Ken es ombri, ken mužer?" 56 by M.M.P., skiing is considered an inappropriate leisure activity for women, whereas in "Il pustu 'Jezero"' an old lady states that swimming in a lake in a bathing suit causes a scandal. We can read: "Maasez di Sedom i Amora ... Ni aj moral, ni aj riguensa.... I estu jaman ejus moda, moral!" ${ }^{7}$ [Stories about Sodom and Gomorrah ... There are no morals or shame ... And they call their fashion moral!]. Sometimes a tone of nostalgia appears: "Ez ki no aj otruz pasatjempus? No ti akordas kuandu huemus muzotras mučačas i rizinkazadas" 58 [Aren't there other pastimes? Don't you remember when we were girls and newlywed?]. Every sign of blurring the limits of masculine and feminine irritates traditional women. They reject the newest women's fashion for short hair, wearing trousers, and even the replacement of tokado ${ }^{59}$ by new hats: "Ken la puede kuniser agora kun esta sjarta moda de čapejos kun una pluma ... ken la puede ver la kara i konoser la" ${ }^{60}$ [Who would recognize her now, wearing these fashionable hats with feathers ... who would see her face and recognize her].

It should be emphasized that the elderly Sephardi women in the stories of Para noče de šabat complain but do not surrender to modern trends and habits. They do not give up their influence on those who are in some way dependent on them. They often head their families, are demanding and strict mothers and mothers-in-law. The total control over family members is to ensure protection, so even if tijas become quite abusive in their control, the narration does not deny them charm and a characteristic sense of humor. In one story it was tija Strulača, not the father of the family, who decisively refused to accept her daughter's fiancé when the young man preferred a different kind of carpet from the one offered in the dowry, and she decided to find a new fiancé: "Mira Ruzitja, si tu madri, fin Sukot, no ti topa novju i no ti meti dibašu di talamu, ki no tenga jo al čarši akeja unor ki tengu" ${ }^{1}$ [Look, Ruzitja, if your mother doesn't find you a fiancé and place you under the wedding canopy until Sukkot, I will lose all the respect I have in the bazaar]. This act proves her courage and ability to oppose established customs and people's opinions, because she broke off her engagement on a wedding day when the party was prepared and the

\footnotetext{
${ }^{56}$ M.M.P., "Ken es ombri, ken mužer?”, Jevrejski glas (1937), 6:7.

${ }^{57}$ Jafi, "Il pustu 'Jezero'."

58 Jakoviku, "Tija Oru i la amiga al gjardin."

59 Traditional hat of the Sephardi women in the Balkans.

${ }^{60}$ Jakoviku, "Tija Oru i la amiga al gjardin."

${ }_{61}$ "Tija Strulača jeva mal kun il jarnu."
} 
rabbi and guests invited. She did not yield to her neighbors' suggestions that it was a disgrace:

Mi djarun umpoku di agua i impisarun las vizinas a dizir mi: ki sto in kaloris grandis, ki avra il ožu luke fagu, ki estu va ser vringuensa. Jo kuandu mi vini umpoku in si, no las iči tinu a ejas ${ }^{62}$

[The neighbors gave me a bit of water and started to talk to me: said that I have a fever, that I should open my eyes and see what I am doing, that it is a shame].

Tija Strulača turns out to be a non-conformist who cares more about her daughter's happiness than about appearances.

The need for control does not diminish even when children leave home to raise their own families with someone from outside the Sephardi community, with whom they will lead a new, modern life. Tija Bijara tries to save her power while checking on her Ashkenazi daughter-in-law during her son's absence:

Kunadu apriti il tilifon, pensati, mi avri la nuera sola. Eja ki mi vidu, ja truko sjen kuloris. No savi luke avlar. Kreji mi ki imprisar a timblar di spantu. . . . Solu kiži asuvir . . . ki veja, ki veja ki no komu paža ${ }^{63}$

[When I rang the doorbell, imagine that, it was my daughter-in-law in person who opened the door. When she saw me, her face displayed hundreds of colors. She didn't know what to say. Believe me, she started to tremble, she was so scared ... I just wanted to go upstairs . . . just to make her see that it is not easy to bribe or fool me].

The Sephardi tijas from the texts of the column seem to be more lenient with their sons than their daughters. As tija Hana and her neighbors admit, daughters are the first to be relied on, but at the same time they can be the greatest burden for the family: "todas mi son bravas: si la Reni, si la Blanki, si la Erna. Mućas vezis digu si no era las dotas i las ašugaris, mas kirija dijes fižas i no un fižu!" ${ }^{4}$ [my all (daughters) are loyal: Reni, Blanki and Erna. I always repeat, if dowries did not exist, I would prefer ten daughters to one son!]. Generally, when it comes to the problem of marrying off children, the conversations present many traditional convictions connected with the subject. They prove the real anxiety of mothers, especially about marrying their daughters. According to a common belief-also reflected in proverbs and sayings-marrying off sons is easier than finding a husband

\footnotetext{
${ }^{62}$ Ibid.

63 "Tija Bijara no komi paža."

${ }^{64}$ Jehi, "Kun il amargu."
} 
for a girl. Tija Bonača from "Loke todo es oj moderno" by Miko Altarac confesses: "Ja, ja, ainda esta sinkena fiža kazalda i ja skapi la bila, a por luz fižos otra vez ez mas kulaj" 65 [I still have the fifth daughter to marry and then my misfortune will end, with sons it is easier].

Mothers' leniency about their boys is also shown by how the sons are allowed to take part in different forms of entertainment, not only typically Jewish, whereas girls are obliged to stay at home and help with household chores. Such a situation can be observed, for example, in "Sretna Nova Godina" by M.M.P. Although tija Merkada does not approve of celebrating non-Jewish festivities, she does not forbid her son Davičon to go out to cafés on the Christian New Year's Eve. Her daughter Blankita is also keen on joining her friends that evening; however, her mother does not let her go out. She explains that the young girl has just come back from work and that many domestic responsibilities await her. The unequal treatment of sons and daughters is best manifested in the following excerpt: "Si a Davičon no lu puedu branijar, a ti si. . . Ti kazaras, il marido si keri ki ti jevi kada noči a la kavane" ${ }^{66}$ [I can't forbid Davičon to do this, but surely I can forbid you. . . . You will get married, your husband, if he wants, will take you every night to a café]. The whole story illustrates Merkada's way of thinking and certain submission to her adult youngest son. By contrast, Blanki depends on her mother and in the future will be expected to obey her husband. The author highlights uneven social norms applied to both genders and shows that this pattern may be prolonged in the next generation as well, as the brother, accustomed to being treated in a better way, speaks to her with an air of superiority and nastiness:

Davičon alegri ki ez fižu i no ez fiža i dragitu di sus vidas para salir, ja si vistjo di ver i no ver i kun una boz sigura, di balabajis, si saludava: - Adiju mama, la javi no premi ki mi deši a la vintana, amanjana di la kavane mi vo ir al fečo. A la sinjora Blankita li aguru buen pasatjempu, shuenju dulsi i sretna nova godina, adiju ${ }^{67}$

[Davičon happy that he is a son and not a daughter and (?) to go out, he dressed up in the twinkling of an eye, and like a self-confident host said goodbye: - See you, mum, there is no need for you to leave the key by the window, as tomorrow I am going to work straight from the café. And I wish miss Blankita fun, sweet dreams and a Happy New Year, bye].

\footnotetext{
${ }^{65}$ Miko Altarac, "Loke todo es oj moderno."

${ }^{66}$ M.M.P., “Sretna Nova Godina,” Jevrejski glas (1937), 3:7-8.

${ }^{67}$ Ibid.
} 
The motif of the leading role of Sephardic women within the family and home zone also appears in some stories which present the image of married couples of older generations. In "Tiju Mušon i las hadras di Pesah," the main male character fulfils many tasks around the house when his wife orders him to do so. From his point of view obeying a woman disrupts the natural order: "Lunis i martis tiju Mušon ja no supu mas si es ombri o mužer.... i tju Mušon, muy abatidu hue sufrjendu estus komandus di tija Rahel" ${ }^{68}$ [On Monday and Tuesday tiju Mušon did not already know if he was a man or a woman.... and tiju Mušon, totally defeated, was suffering because of the commands of tija Rahel...]. What is significant is that the subordination to his wife and the man's attempts to save the shreds of his control and male dignity are described with a dose of sympathy, but also in a very humoristic way.

More often than not, the story collection indicates the minor position of the Sephardi tijas in marriages, and the descriptions seem to lack sympathy for the female characters. One easily observes that even if the Sephardi wives grumble and complain, it is men who are to decide and explain the rules and phenomena of the life in the community, as in the conversation between Avram and his wife, tija Simhula:

- Ma loke mi vas tu a mi ambezar loke vo jo azer, kajada ke te stes i ninguna de tu boka no kero sintir, ja sto farto de ti. Si tu solo un poko pensavas, tu a mi nada no me avlavas. No se komo no ez a ti avriguensa i avlar. Tu a mi dar konsežo? ... kavesa di mulja ... kavesa di bova....

- No si aravje, mi Avramači, jo nada no diši, solo sto pensando. Na la đente, la đente...

- Ma kvala đente ... luke ti ves a la đente ... Đente ez đente, ke avli kado uno lo ke keri. Ken puede tapar la boka de la đente del mundo entero. ${ }^{69}$

[- But how are you going to teach me, what should I do, shut your mouth, I don't want to hear it any more, I am sick and tired of you. If only you thought a little, you wouldn't say anything. I don't know why you aren't too embarrassed to talk. And you want to give me advice? ... you bonehead.

- Don't get mad, my Avramači, I didn't say anything, I was just thinking. But people, people...

- But which people ... do you care about them? People are people, let them say what they want. Who could silence people of the whole world?].

The Sephardi women's subordination is additionally portrayed through male characters in the story. Females are not very present in religious

${ }^{68}$ Josefiko, “Tiju Mušon i la hadras di Pesah,” Jevrejski glas (1932), 17-18:11.

${ }^{69} \mathrm{Mi}$, “Tija Simhula,” Jevrejski glas (1932), 12:6. 
life, which does not make them very useful within the community or even family:

Vejis komo sož las mužeris? Pikaš, pikaš no savjendu! Il ombri es in kaza una đoja in kadiš, diremus, la mužer no ti puedi dizir. Una micva no puedi azer, keru dizir una micva en la keila ${ }^{70}$

[Can you see what you are like, women? You can only open your big mouths, but you don't know anything! A man is a treasure at home, let's take kaddish, for example, a woman can say so. And she can't do mitzvah, I mean mitzvah in kehillah].

The justification is often underlined with a Sephardi proverb which the male characters repeat among themselves: "Feću di mužeris, kavejus longus i sehel kurtu" ${ }^{11}$ [It is the female thing, long hair and short sense!]. The descriptions confirm the image of the Sephardi women (especially tijas) who are not very active in the official life of the community, are limited to the zone of the closest surroundings, and get easily confused beyond it. Furthermore, the male point of view shows them to be incapable of making independent decisions.

\section{Conclusions}

The strategy of keeping in script the memory of Sephardi culture and Judeo-Spanish tradition, which was fading away at that time, was proposed by the editors of the periodical Jevrejski glas in the column Para noče de šabat and carried out thanks to the contributions of readers. The approach was based on the image of Sephardi men and, above all, women of elderly generations. Their lives embodied a "true Sephardi spirit" in which we can see the crucial role of religion, related customs, and clear divisions of male and female spheres as well as Jewish and non-Jewish ones. The editors considered Judeo-Spanish to be the most appropriate means of describing it, first of all, because in that period in the region this language was still inseparably associated with the concept of the "Sephardi spirit," which was to be preserved in the stories. The analysis of the texts published in the column shows that in the early 1930s women were recognized as anchors for this traditional lifestyle, and their depictions prevailed when different aspects of old ways of living were illustrated. The characters appear in the circle of family and neighbors, within the Jewish neighborhood-in the

\footnotetext{
${ }^{70}$ Jehi, "Kun il amargu."

${ }^{71}$ Ibid.
} 
space customarily perceived as feminine. At that time, it was irreparably decreasing and its limits were getting vague and frequently crossed into other spaces (e.g. the one earlier reserved for men or for other ethnic and religious groups). Apart from the representations of everyday, vernacular life and various manifestations of mentality founded on religion and traditional social and gender patterns-mostly in their female variants-the clash between the old order and the invading modernity was reflected too. That is why in the collected texts one can observe resentment toward social and cultural changes, toward extending living-space of the Sephardi community, contacts with non-Jews and even with Ashkenazi Jews. Nevertheless, all the aspects and motives in the gathered stories are presented with care, in a nostalgic or humorous way, with lively, picturesque, vernacular language-Judeo-Spanish in the local sub-dialect, which definitely deserves a separate, comprehensive description.

The basic account of the female image proposed in this article may serve as a point of departure for further analyzes aimed at making comparisons with less amateurish and non-anonymous texts in the Sarajevian weeklies Jevrejski glas and Jevrejski život. Moreover, a parallel might be drawn between the texts in Para noče de šabat and works that perceive the Sephardi tradition and women's roles from a decidedly female point of view-Laura Papo's short stories and theater plays and her ethnographic study La mužer sefardi de Bosna.

Aleksandra Twardowska Nicolaus Copernicus University in Toruń atwardowska@umk.pl

Agnieszka August-Zarębska

University of Wrocław agnieszka.august-zarebska@uwr.edu.pl 